\title{
Phytochemical and Morphological Attributes of Borage (Borago officinalis) Affected by Salicylic Acid as an Enhancer
}

\author{
Vahid AKBARPOUR*, Hossein ARUEI, Seyyed Hossein NEMATI
}

Department of Horticulture, International Branch of Ferdowsi University of Mashhad, Mashhad, Iran;

v_akbarpour@yahoo.com ("correspondingauthor)

\begin{abstract}
The objective of this study was to determine the response of borage (Borago officinalis) phytochemical and morphological attributes in relation to application of different levels of salicylic acid. Borage planted in pots and salicylic acid was sprayed on the shoots at concentrations of $0,0.5,1.0$ and $1.5 \mathrm{mM}$ with 6 replications in a completely randomized block design. Morphological attributes such as shoot height, shoot dry matter, flower dry matter, flower weight and shoot wet weight were measured. In the other hand, phytochemical attributes such as ion leakage, chlorophyll $a, b$, carotenoid, and antioxidant activity were also investigated under induced stress by different concentrations of salicylic acid. Results showed that some morphological traits such as shoot dry matter (31.23\%), flower dry matter (20.43\%), flower weight $(38.54 \mathrm{~g})$, shoot wet weight $(109.43 \mathrm{~g})$, possessed the highest values under treatment of $1.5 \mathrm{mM}$ salicylic acid. Also, some phytochemical traits in plants treated with $1.5 \mathrm{mM}$ salicylic acid reached the highest values during the growth stage with the exception of ion leakage $(0.54 \%)$. These measured traits with higher values consisted of chlorophyll $a\left(4.16 \mathrm{mg} \cdot \mathrm{l}^{-1}\right)$, chlorophyll $b\left(1.65 \mathrm{mg} \cdot \mathrm{l}^{-1}\right)$, total chlorophyll $\left(5.81 \mathrm{mg} . \mathrm{l}^{-1}\right)$, carotenoid $\left(1.18 \mathrm{mg} \cdot \mathrm{l}^{-1}\right)$, antioxidant activity (53.73\%).
\end{abstract}

Keywords: Borage, medicinal plants, morphological, phytochemical attributes, salicylic acid

\section{Introduction}

Borage (Borago officinalis L.) is a herbaceous annual plant belonging to the Boraginaceae family (Janick $e t$ al., 1989). A recent study proved that the presence of biologically certain active compounds is responsible for the pharmacological activity in dried flowers of borage. Thus, it can be valuable source of inflammation removal substances and promotion of skin regeneration, being is effective in treatment of eczema and wounds (Berti et al., 2012; Marzena et al., 2012).

Plant growth regulators stimulate growth and secondary metabolites' biosynthesis in various aromatic plants (Shukla et al., 1992). Salicylic acid is one of the plant growth regulators, which is involved in various plant physiological processes, such as growth regulation, photosynthesis, flower induction, nutrient uptake, plant water relations and mechanisms of plant resistance and tolerance to biotic and abiotic stresses (Hayat et al., 2010; Popova et al., 1997). Several studies have demonstrated that exogenous salicylic acid application enhances plant growth and development. Al-Shareif (2006) showed that spraying on Carum carvi plants with salicylic acid at different concentrations significantly increased vegetative growth parameters, including plant height, branch number and herb dry weights/plant, essential oil percentage and oil yield/plant. Fariduddin et al. (2003) reported that mustard plants sprayed with low concentrations of salicylic acid produced larger amounts of dry matter and had higher photosynthetic rate in comparison with control plants. In another study, the effect of salicylic acid on silymarin; linoleic acid content and lipoxigenase activity in hairy root cultures of Solanum marianium treated with salicylic acid was reported. Nivedithadevi et al. (2010) also found all plants treated with salicylic acid to have more whole plant fresh weight, dry weight, root length and stem length. They also stated that after the leaves' pigment analysis, chlorophyll, carotenoid, anthocyanin and xanthophylls pigment contents were increased due salicylic acid treatments. In addition, Hussein et al. (2011) revealed that growth traits of maize plants were improved as a result of spraying salicylic acid on the plants. Salicylic acid application on corn and soybean also resulted in growth of leaf area and dry weight of plants (Khan et al., 2003; Hayat et al., 2005).

Based on the mentioned reports, application of salicylic acid plays important role in achieving the maximum potential of productivity in crop plants. It can also affect the growth and development of medicinal plants and the accumulation of active substances in their organs (Azhar 2011; Haripriya et al., 2010). While suitable concentration of this growth regulator, in different plants, is known to raise the concentration of secondary metabolites (Selmar, 2008; Zobayed et al., 2007), it also has to be taken into consideration in case of borage medicinal plant.

Despite of studies regarding the response of different plants to exogenous application of salicylic acid in various 
conditions, there is no information available about borage response to salicylic acid application.

The aim of this study was to determine the phytochemical and morphological attributes of borage (Borago officinalis) in relation to application of different levels of salicylic acid.

\section{Materials and methods}

This research was conducted with the objective of evaluating the effect of various concentrations of salicilyc acid on the morphological and phytochemical characteristics of the Borago officinalis medicinal plant.

The experiment was arranged in a completely randomized design with four replications. Treatments consisted of various salicylic acid concentrations of: $0,0.5,1.0$ and $1.5 \mathrm{mM}$. Spraying was done four times at 15 -days intervals. Finally, at the end of the experiment, the attended parameters were measured and recorded.

Morphological attributes

Plants harvested at full bloom were transferred to laboratory for some morphological attributes record, such as shoot height, shoot wet weight and flower weight. Flowers and shoots were oven dried (Model BM120, Iran) with a temperature of $40{ }^{\circ} \mathrm{C}$ for 72 hours and their dry matters were calculated.

\section{Phytochemical attributes}

Ion leakage

Ion leakage percentage was calculated after the following phases: two distilled washed leaf discs were put into $10 \mathrm{ml}$ of double distilled water, and after transferring from the overnight holding temperature of $25^{\circ} \mathrm{C}$, the electric conductivity of the solution was measured $(\mathrm{Lt})$. Then sample tubes were put into the autoclave with the temperature of $120{ }^{\circ} \mathrm{C}$ for one hour and the recorded electric conductivity expressed as Lo. Finally, the ion leakage was calculated based on the below formula (Simon, 1977):

$$
I L=\frac{L t}{L o} * 100
$$

Chlorophyll a, b and carotenoid

Total leaf chlorophyll content (SPAD value) was measured using chlorophyll meter (SPAD 502, Minolta Japan). A method introduced by Pora et al. (2002) was used to measure and calculate the amount of chlorophyll a $(665.2$ $\mathrm{nm})$ and b (652 nm) and also carotenoids content determined using spectrophotometer (6405 UV/Vis Jenway, England) and expressed as $\mathrm{g}$ per $\mathrm{ml}$ via following equations:

$[$ Chla $]=16.29 E 665.2-8.45 E 652$

$[$ Chlb $]=30.66 E 652-13.58 E 665.2$

$[\mathrm{Chl} \mathrm{a}+\mathrm{b}]=22.12 \mathrm{E} 652+2.71 \mathrm{E} 665.2$

$[$ Carotenoid $]=\frac{[(1000 \times \mathrm{A} 470)-1.63 \times \mathrm{Chl} \mathrm{a}-(104.96 \times \mathrm{Chl} \mathrm{b})]}{221}$

Antioxidant activity Antioxidant capacity was determined by neutralizing properties of free radical DPPH (Ebrahimzadeh et al., 2010). $100 \mathrm{ml}$ of the extract was centrifuged and $2900 \mathrm{ml}$ DPPH solution was added.
Mixture was quickly stirred and maintained at room temperature for $15 \mathrm{~min}$ in dark conditions. The decrease in absorption was determined at a wavelength of $515 \mathrm{~nm}$ using a spectrophotometer (model uv-1800 PC, Japan). Afterwards, the antioxidant capacity of the extracts was calculated and expressed as the inhibition percentage of $\mathrm{DPPH}$

$$
\begin{aligned}
& \% D P P H s c=\left(A_{\text {cont }}-A_{\text {samp }}\right) \times 100 / A_{\text {cont }} \\
& \mathrm{A}_{\text {samp }}=\mathrm{DPPH}+\text { Absorption of the sample } \\
& \mathrm{A}_{\text {cont }}=\text { Absorption of DPPH } \\
& \text { Percentage of inhibition }=\% \mathrm{DPPHsc}
\end{aligned}
$$

\section{Results}

The ANOVA indicated that all measured attributes of borage plant were significantly affected by the different treatments of salicylic acid, with the exception of shoot dry matter.

\section{Morphological attributes \\ Shoot height}

Plants treated with $1.5 \mathrm{mM} \mathrm{SA}$ produced the highest shoot height, so that it reached to maximum as compared to the control, showing a significant difference (Tab. 1).

\section{Shoot dry matter}

Considering that no significant difference was found between treatments in terms of control plants shoot dry matter, but the control plants possessed the minimum shoot dry matter and plants grew under $1.5 \mathrm{mM} \mathrm{SA}$ possessed the maximum ones (Tab. 1).

\section{Flower dry matter}

The highest flower dry matter was recorded at $1.5 \mathrm{mM}$ SA and show significant difference with control. The plants under 0.5 and $1.0 \mathrm{mM} \mathrm{SA}$ followed an ascending trend and had no significant differences with each other, with control nor the highest level of SA (Tab. 1).

\section{Flower weight}

Flower weight showed a significant and ascending trend from control to $1.5 \mathrm{mM} \mathrm{SA}$, while there was no significant difference between two intermediate levels of SA (Tab. 1).

\section{Shoot wet weight}

There was no significant difference between the two high levels of SA (1.0 and $1.5 \mathrm{mM}$ ), while these levels had significant difference with $0.5 \mathrm{mM} \mathrm{SA}$ and the control.

Tab. 1. Effect of different salicylic acid concentrations on different morphological attributes

\begin{tabular}{cccccc}
\hline \multirow{2}{*}{$\begin{array}{c}\text { Salicylic } \\
\text { acid } \\
(\mathrm{mM})\end{array}$} & $\begin{array}{c}\text { Shoot } \\
\text { height } \\
(\mathrm{cm})\end{array}$ & $\begin{array}{c}\text { Shoot } \\
\text { dry } \\
\text { matter } \\
(\%)\end{array}$ & $\begin{array}{c}\text { Flower } \\
\text { dry } \\
\text { matter } \\
(\%)\end{array}$ & $\begin{array}{c}\text { Flower } \\
\text { weight } \\
(\mathrm{g})\end{array}$ & $\begin{array}{c}\text { shoot } \\
\text { wet } \\
\text { weight } \\
(\mathrm{g})\end{array}$ \\
\hline 0 & $47.26 \mathrm{c}$ & $27.49 \mathrm{a}$ & $15.97 \mathrm{~b}$ & $20.34 \mathrm{c}$ & $64.72 \mathrm{c}$ \\
0.5 & $48.60 \mathrm{bc}$ & $28.07 \mathrm{a}$ & $17.56 \mathrm{ab}$ & $28.83 \mathrm{~b}$ & $80.11 \mathrm{~b}$ \\
1 & $52.40 \mathrm{ab}$ & $29.23 \mathrm{a}$ & $17.80 \mathrm{ab}$ & $32.52 \mathrm{~b}$ & $99.51 \mathrm{a}$ \\
1.5 & $54.00 \mathrm{a}$ & $31.23 \mathrm{a}$ & $20.43 \mathrm{a}$ & $38.54 \mathrm{a}$ & $109.43 \mathrm{a}$ \\
\hline
\end{tabular}


140

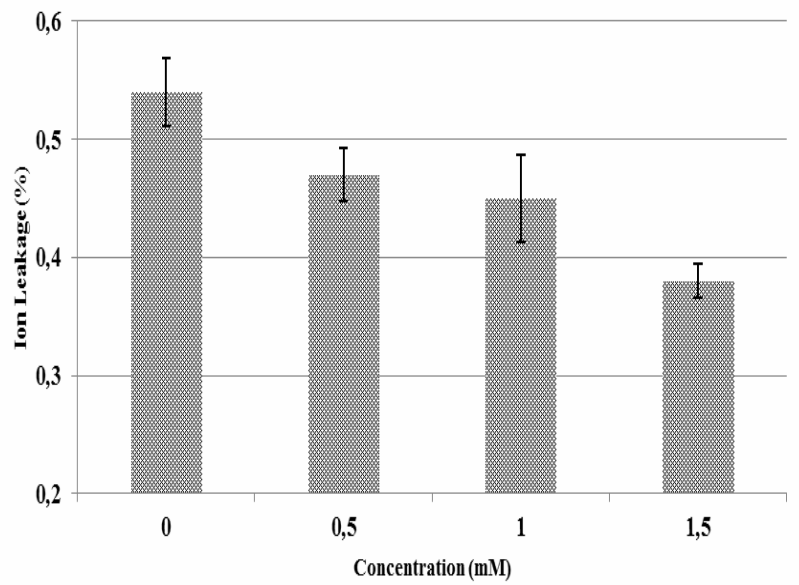

Fig. 1. Effect of different concentrations of SA on ion leakage

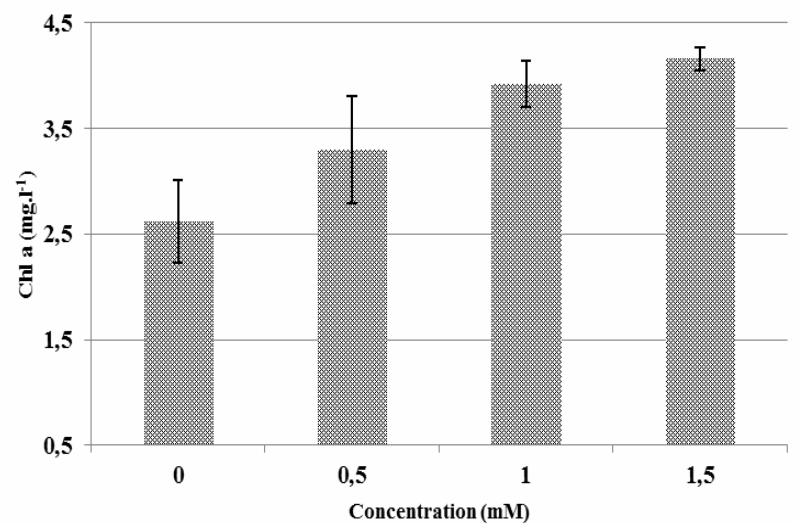

Fig. 1. Effect of different concentrations of SA on chlorophyll a content

\section{Phytochemical attributes}

\section{Ion leakage}

As it can be seen in Fig. 1, the ion leakage was significantly affected by various concentrations of SA. The greatest increase in ion leakage $(0.54 \%)$ was found at control plants and a descending trend was observed toward the high concentration of SA.

\section{Chlorophyll a}

Although there was neither significant difference between two upper SA concentrations (1.5 and $1 \mathrm{mM}$ ) nor between two lower concentrations ( 1 and $0 \mathrm{mM}$ ), an increasing trend of chlorophyll a content was recorded. As shown in Fig. 2, the lowest chlorophyll a content belonged to the control, while the highest belonged to $1.5 \mathrm{mM} \mathrm{SA}$ concentration.

\section{Chlorophyll b}

No significant difference was observed between control and the lowest concentration $(1.0 \mathrm{mM})$ of $\mathrm{SA}$ for chlorophyll $b$ content, but a significant difference was recorded between the highest $(1.5 \mathrm{mM})$, the intermediate $(1.0 \mathrm{mM})$ and the lowest concentration of SA (Fig 3).

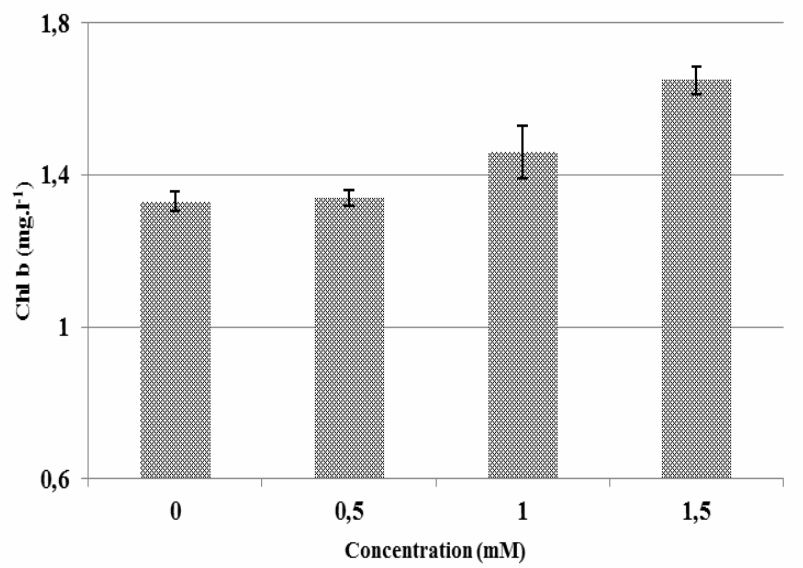

Fig. 3. Effect of different concentrations of SA on chlorophyll b content

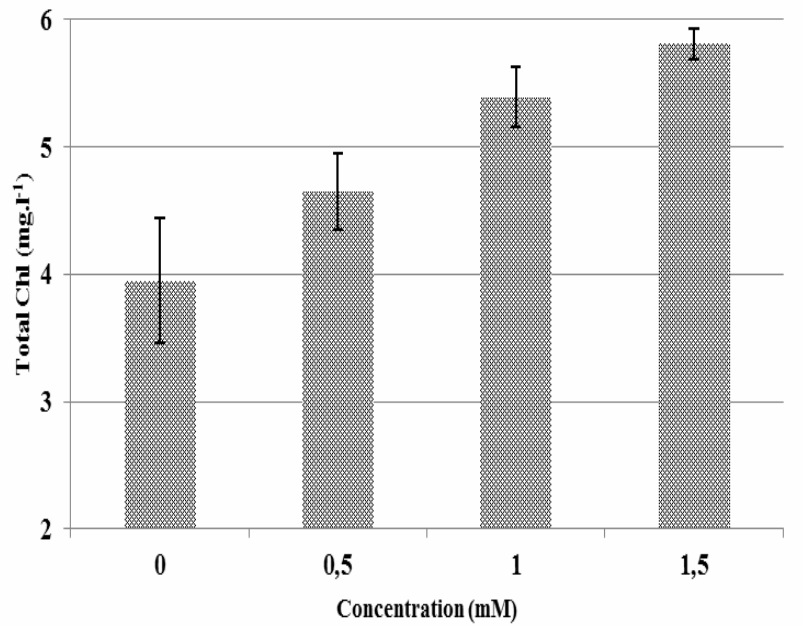

Fig. 4. Effect of different concentrations of SA on total chlorophyll content

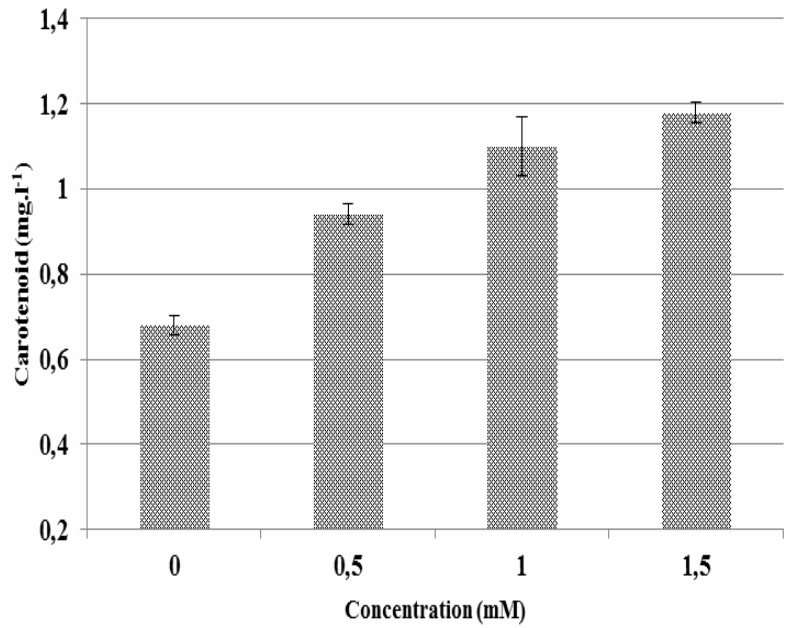

Fig. 5. Effect of different concentrations of SA on carotenoid content 


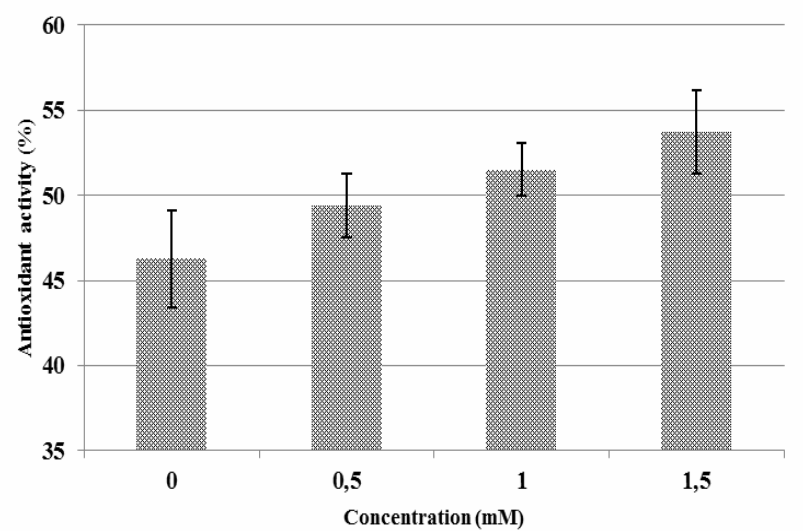

Fig. 6. Effect of different concentrations of SA on antioxidant activity

\section{Total chlorophyll}

Results showed that samples followed an ascending trend for total chlorophyll from control $\left(3.95 \mathrm{mg} . \mathrm{l}^{-1}\right)$ to the highest (5.81 mg. ${ }^{-1}$ ) SA concentration (Fig 4).

\section{Carotenoid}

The most carotenoid amount was recorded at the highest SA level $\left(1.18 \mathrm{mg} \cdot \mathrm{l}^{-1}\right)$ and the lowest amount was presented at the control $\left(0.68 \mathrm{mgl}^{-1}\right)$. All levels of SA represented significantly different amounts of carotenoid (Fig 5).

\section{Antioxidant activity}

There was significant difference between control and plants treated with high concentration of SA for antioxidant activity. Hence, no significant difference between control and plants treated with $0.5 \mathrm{mM} \mathrm{SA}$ was observed and the same pattern for plants treated with 1.0 $\mathrm{mM}$ and $1.5 \mathrm{mM} \mathrm{SA}$. In the other hand, plants under 0.5 and $1.0 \mathrm{mM} \mathrm{SA}$ condition were not significantly different for antioxidant activity (Fig. 6).

\section{Discussion and conclusions}

As the results showed, some morphological and phytochemical traits in plants treated with $1.5 \mathrm{mM}$ salicylic acid reached the highest values. This growth regulator causes the number of flowers by increasing protein production and isosymes bands formation (Khurama et al., 1992). Salicylic acid also retards senescence and increase the flowering and flower life (Metwally et al., 2003). Plants may act differently facing to stresses; one of them is stress avoid by completing growth cycle and leads to early flowering and seed formation (Hapkinz, 1999). Since salicylic acid is one of the growth regulators produced under stress conditions, it seems that spraying it on plants can control physiological actions such as increment of cell number and size (khan et al., 2003; Popova et al., 2003). These actions are the interaction of salicylic acid and other growth regulators such as auxin and cytokinens (Taiz and Zeiger, 1999). Several reports have been shown the positive effects of salicylic acid; in soy bean and cucumber (Gutierrez-Coronado et al., 1998); odor violet (Hussain et al., 2011). The inductive effects of this hormone on growth can be related to increase of cell division in meristem zones and also its effects on other growth regulators (Shakirova et al., 2003).

This growth regulator also affects the photosynthetic pigments. Suitable concentrations of salicylic acid inhibit chlorophyll degradation and increases photosynthesis. This action occurs by inhibition of chlorophyll oxidase enzyme activity (Belkhadi et al., 2010). Increment of chlorophyll content improves the photosynthesis and better growth (Hapkinez, 1999). Salicylic acid effect on pigments content depending on its concentration as investigated on oregano, sweet basil and barley (Gharib, 2006; Canakci and Munzuroghlu, 2009). Singh et al. (2010) found that application of salicylic acid increased the nitrogen, protein and nitric reductase in cucumber. Based on their report, it is concluded that salicylic acid may increase the chlorophyll content by indirectly increment of nitrate reductase activity and nutrient uptake.

Several factors can affect the carotenoid content such as application of fertilizers or growth regulators. It seems that application of salicylic acid act as a hardening procedure and increase the cell antioxidant activity which leads to cell membrane protection and photosynthetic pigments synthesis and finally improves the growth indexes and secondary metabolites synthesis (Momeny et al., 1391). Duysen and Freman (1975) reported that salicylic acid is a pigments regulator factor under stress condition which plays its role by regulating the ethylene content.

In conclusion, these results could suggest that salicylic acid protects plants against biotic and abiotic stresses and enhance their resistance to damages, so it has had a positive impact on most of the mentioned traits and can be used as one of the promising growth regulators in medicinal plants.

\section{References}

Al-Shareif AMO (2006). Response of caraway plants grown in sandy soil under drip irrigation system to some biofertilization and antioxidants treatments. M.Sc. Thesis, Fac. Agric, Minia Univ.

Azhar N, Hussain B, Ashraf MY, Abbasi KY (2011). Water stress mediated changes in growth, physiology and secondary metabolites of Desi Ajwain (Trachyspermum ammi L.). Pak J Bot 43:15-19.

Belkhadi A, Hediji H, Abbes Z, Nouairi I, Barhoumi Z, Zarrouk M, Chaibi W, Djebali W (2010). Effects of exogenous salicylic acid pre-treatment on cadmium toxicity and leaf lipid content in Linum usitatissimum L. Ecotox Environ Safe 73(5):1004-11.

Berti MT, Fischer SU, Wilckens RL, Hevia MF, Johnson BL (2010). Borage (Borago officinalis L.) response to N, P, K, and $S$ fertilization in south central Chile. Chilian J Agric Res 70(2):228-236.

Canakci S, Munzuroghlu O (2009). Effect of salicylic acid on growth and chlorophyll destruction of some plant tissues. World Journal of Agricultural Sciences 5(5):577-581.

Duysen ME, Freman TP (1976). Promotion of plastid pigment accumulation in water stressed what leaf section by hormone treatment. Am J Bot 63(8):1134-1141. 
142

Ebrahimzadeh MA, Nabavi SM, Nabavi S.F, Bahramian F, Bekhradnia AR (2010). Antioxidant and ferric radical scavering activity of $H$. officinalis L. var angustifolius, $V$. odorata, B. hyrcana and C. speciosum. Pak J Pharm Sci 23(1):29-34.

Fariduddin Q, Hayat S, Ahmad A (2003). Salicylic acid influences net photosynthetic rate, carboxylation efficiency, nitrate reductase activity and seed yield in Brassica juncea. Photosynthetica 41:281-284.

Gharib FAE (2006). Effect of salicylic acid on the growth, metabolic activities and oil content of basil and marjoram. Int J Agr Biol 4:485-492.

Gutierrez-Coronado MA, Trejo-Lopez C, Larqué-Saavedra A (1998). Effects of salicylic acid on the growth of roots and shoots in soybean. Plant Physiol Bioch 36(8):563-565.

Hapkins WG (1999). Introduction to plant physiology. Vol 1 and 2, John Wiley and Sons, New York.

Haripriya M, Vijaya T, Mouli KC (2010). Effect of water stress on growth, metabolic activities of Withania somnifera-an important phytoceutical plant: Ameliorative effects of VAM. J Glob Pharma Tech 2:112-116.

Hayat Q, Hayat S, Irfan M, Ahmad A (2010). Effect of exogenous salicylic acid under changing environment: A review. Environ Exp Bot 68:14-25.

Hayat S, Fariduddin Q, Ali B, Ahmad A (2005). Effect of salicylic acid on growth and enzyme activities of wheat seedlings. Acta Agron Hung 53:433-437.

Hussein MM, Balbaa LK, Gaballah MS (2011). Salicylic acid and salinity effects on growth of maize plants. Res J Agric Biol Sci 3:321-328.

Janick J, Simon JE, Quinn J and Beaubaire N (1989). Borage: A source of gamma linolenic acid. In: Craker LE, Simon JE (eds.), p.145-168. Herbs, spices, and medicinal plants. Recent advances in botany, horticulture, and pharmacology. Haworth Press, New York, USA.

Khan W, Prithviraj B, Smith DL (2003). Photosynthetic responses of cornand soybean to foliar application of salicylates. J Plant Physiol 160:485-492.

Khurama JPS, Cleland CF (1992). Role of salicylic acid and benzoic acid in flowering of photoperiodin sensitive strain, Lemna paucicostata LP6. Plant Physiol 100:1541-1546.

Metwally A, Finkemeier I, Georgi M, Dietz KJ (2003). Salicylic acid alleviated the cadmium toxicity in barley seedling. Plant Physiol Bioch 132:272-281.
Momeny N, Arvin MJ, Khajuinezhad Gh, Keramat B, Daneshmand $\mathrm{F}$ (2012). Effect of $\mathrm{NaCl}$ and salicylic acid on some photosynthetic indexes and mineral nutrition of maize (Zea mays L.). Plant Biol 5(15):15-30.

Nivedithadevi D, Somasundaram R, Pannerselvam R (2012). Effect of abscisic acid, paclobutrazol and salicylic acid on the growth and pigment variation in Solanum trilobatum. Int J Drug Develop and Res 4(3):237-246.

Popova L, Pancheva T, Uzunova A (1997). Salicylic acid: properties, biosynthesis and physiological role. Bulg J Plant Physiol 23:85-93.

Popova L, Ananieva V, Hristova V, Christov K, Georgieva K, Alexieva V, Stoinova Zh (2003). Salicylic acid and methyl jasmonate induced protection on photosynthesis to parquet oxidative stress. Bulgarian J Plant Physiol, Special Issue:133152.

Porra RJ (2002). Thechequered history of the development and use of simultaneous equations for the accurate determination of chlorophylls $a$ and $b$. Photosynth Res 73:149-156.

Selmar D (2008). Potential of salt and drought stress to increase pharmaceutical significant secondary compounds in plants. Landbauforsch 58:139-144.

Shakirova FM, Sakhabutdinova AR, Bozrutkova MV, Fatkhutdinova RA, Fatkhutdinova DR (2003). Changes in the hormonal status of wheat seedlings induced by salicylic acid and salinity. Plant Sci 164:317-322.

Shukla A, Abad Farooqi AH, Shukla, Sharma S (1992). Effect of triacontanol and chlormequat on growth, plant hormones and artemisinin yield in Artemisia annua L. Plant Growth Regul 11:165-171.

Simon EW (1977). Leakage from fruit cells in water. J Exp Bot 28:1147-1152.

Singh PK, Chaturvedi VK, Bose B (2010). Effects of salicylic acid on seedling growth and nitrogen metabolism in cucumber (Cucumis sativus L.). J Stress Physiol and Biochem 6(3):102113.

Taiz L, Zeiger E (1999). Plant Physiology. Benjamin Cummings Publishing Company, New York.

Zobayed SMA, Afreen F, Kozai T (2007). Phytochemical and physiological changes in the leaves of St. John's wort plants under a water stress condition. Environ Exp Bot 59(2):109-116. 